New Zealand Foreign Policy Under the Clark Government: High Tide of Liberal Internationalism

Author(s): David McCraw

Source: Pacific Affairs, Vol. 78, No. 2 (Summer, 2005), pp. 217-235

Published by: Pacific Affairs, University of British Columbia

Stable URL: http://www.jstor.org/stable/40023914

Accessed: 14/11/2013 21:13

Your use of the JSTOR archive indicates your acceptance of the Terms \& Conditions of Use, available at http://www.jstor.org/page/info/about/policies/terms.jsp

JSTOR is a not-for-profit service that helps scholars, researchers, and students discover, use, and build upon a wide range of content in a trusted digital archive. We use information technology and tools to increase productivity and facilitate new forms of scholarship. For more information about JSTOR, please contact support@jstor.org. 


\title{
New Zealand Foreign Policy Under the Clark Government: High Tide of Liberal Internationalism?
}

\author{
David McCraw
}

$\mathrm{T}$

The foreign policy of the current New Zealand government has strongly reflected the Labour Party's Liberal Internationalist ideology. Indeed, it is probable that this government has been the most Liberal Internationalist of all New Zealand Labour governments. The government of Prime Minister Helen Clark has placed considerable emphasis on the promotion of human rights internationally; it has strongly supported the role of the United Nations; it has championed nuclear disarmament and restructured the New Zealand armed forces to prioritize peacekeeping; and it has vigorously promoted free trade. Like all New Zealand governments, however, the Clark government's foreign policy has not always reflected its ideological predisposition, although the exceptions have been relatively few so far.

The two major political parties in New Zealand, National and Labour, have differing outlooks on foreign affairs, which correspond quite well with the two classical approaches to international relations, Realism and Liberal Internationalism. ${ }^{1}$ The Labour Party's outlook may be characterized as basically Liberal Internationalist, whereas the National Party's is essentially Realist. When in government, these two different outlooks have influenced their respective parties' foreign policies considerably, although not in a consistent way, since governments are subject to many influences. Thus Labour governments have tended to have more Liberal Internationalist policies than Realist ones, and National governments the reverse.

Liberal Internationalism is a school of thought about international relations that is mainly associated with the outlook of President Woodrow Wilson of the United States, although it is rooted in the ideas of Enlightenment thinkers such as Kant and Locke. The liberal approach to international relations begins with a belief in the common interests of the

1 David McCraw, "Realism and Idealism in New Zealand's Foreign Policy," New Zealand International Review, vol. 23, no. 4 (July-August 1998), pp. 18-21. 
world's people and the possibility of cooperation between nations for the common good. Obstacles to cooperation are thought to be the result of flawed governments or social systems. Wilson believed that peaceful relations between nations could be encouraged by the promotion of democracy, human rights and self-determination. Peace could also be advanced by the establishment and strengthening of international institutions, the promotion of disarmament and arms control, and the encouragement of free trade between nations. These propositions are still at the core of modern liberal thought, known as neoliberalism. ${ }^{2}$

Liberal Internationalism is opposed by another school of thought known as Realism. Realism, like Liberal Internationalism, has a number of varieties, but they share some core propositions, such as the belief that relations between states are inherently conflictual, not cooperative, and that a state's priority must be the advancement of the national interest. Realists see the state's survival as the greatest national interest, and thus give great importance to security. ${ }^{3}$ Realists are more sceptical than Liberals about the prospects for international cooperation, and are thus less enthusiastic about international institutions. ${ }^{4}$ The promotion of human rights and democracy is much lower on the Realist agenda than on the Liberal one. Realists tend to believe that governments should not interfere in the internal business of other states. ${ }^{5}$

The New Zealand Labour Party has traditionally been anti-militarist, enthusiastic about the United Nations, and concerned about human rights, all of which are elements of the Liberal Internationalist outlook. Labour has not, however, traditionally been a free-trade party, but in 1984 it changed course and has since championed free trade. Thus, the party now espouses all the major elements of Liberal Internationalism.

The New Zealand National Party, in contrast, has always been concerned about New Zealand's security, has taken a low-key and pragmatic attitude to human rights issues in other countries, and has been less enthusiastic about the United Nations than Labour. This set of attitudes puts it closer to Realism than Liberal Internationalism. ${ }^{6}$

At the 1999 election, the Labour Party came to power as the dominant party in a minority coalition formed with the Alliance Party. Labour retained

2 Charles W. Kegley, Jr., “The Neoliberal Challenge to Realist Theories of World Politics: An Introduction," in Charles W. Kegley, Jr, ed., Controversies in International Relations Theory: Realism and the Neoliberal Challenge (New York: St. Martins Press, 1995), pp. 9-14.

3 Robert G. Gilpin, "No One Loves a Political Realist" in Benjamin Frankel, ed., Realism: Restatements and Renewal (London: Frank Cass, 1996), pp. 7-8.

4 Joseph M. Grieco, "Anarchy and the Limits of Co-operation: A Realist Critique of the Newest Liberal Institutionalism," in Charles W. Kegley, Jr., ed., Controversies in International Relations Theory: Realism and the Neoliberal Challenge (New York: St Martins Press, 1995), p. 151.

5 See, for instance, George F. Kennan, “Morality and Foreign Policy," Foreign Affairs, vol. 64, no. 2 (Winter 1985-86), p. 209.

6 McCraw, "Realism and Idealism in New Zealand's Foreign Policy," pp. 19-20. 
power after the 2002 election by forming another minority coalition with the Progressives. In both cases the coalition partners were ideologically close to Labour. The government was supported on confidence votes by sympathetic parties who were not formal allies.

This Labour coalition government has probably been the most Liberal Internationalist of all New Zealand governments so far. This conclusion results from an examination of the main issues confronted by the Clark government in each area that Liberal Internationalism emphasizes: the promotion of human rights internationally, support for international institutions, antimilitarism and the encouragement of free trade. No other New Zealand government has been as consistently strong in all four areas.

\section{Human Rights, Democracy and Self-Determination}

Small states such as New Zealand are thought by some scholars to have a greater tendency than large ones to espouse moral or idealist causes in their foreign policies. ${ }^{7}$ In New Zealand, however, the promotion of human rights and democracy in the world has been associated almost exclusively with Labour Party governments. ${ }^{8}$ The first Labour government played a significant part in ensuring that human rights were included in the United Nations Charter, and a later party manifesto was to claim that the party's international affairs policy was to promote the International Declaration of Human Rights. ${ }^{9}$ National party governments have tended to give a lower priority to human rights promotion. The party's foreign policy is focussed instead on New Zealand's economic and security interests. The minister of foreign affairs in the last National government declared that New Zealand could not afford to be hindered by a single ideological approach; nor should it take the moral high ground on every international issue of the day, or feel that it had some divine right to lecture the world. ${ }^{10}$

Shortly after the current government came to power, Foreign Minister Phil Goff announced that the change in government would mean a change of priorities and emphases in foreign policy, and a month later Prime Minister Helen Clark was to state that one of the new priorities would be human rights issues. ${ }^{11}$

7 Maurice A. East, "Size and Foreign Policy Behavior: A Test of Two Models," World Politics, vol. 25, no. 4 (July 1973), p. 557.

8 David J. McCraw, "New Zealand's Foreign Policy under National and Labour Governments: Variations on the 'Small State' Theme?” Pacific Affairs, vol. 67, no. 1 (Spring 1994), pp. 20-23.

9 Paul Lauren, “'A Very Special Moment in History': New Zealand's Role in the Evolution of International Human Rights," New Zealand International Review, vol. 23, no. 6 (November-December 1998), pp. 2-9; New Zealand Labour Party, 1972 Election Manifesto (Wellington: New Zealand Labour Party, 1972), p. 29.

10 Waikato Times, 11 February 1992, p. 1.

11 Phil Goff, "Where to in Foreign Policy?" and Helen Clark, "New Zealand Foreign Policy: Pushing the Big Ideas," both in New Zealand International Review, vol. 25, no. 4 (July-August 2000), pp. 5-6. 
The prime minister's declaration was put to the test almost immediately with regard to a crisis in Fiji. Fiji is one of New Zealand's closest neighbours and a fellow member of the Commonwealth and the Pacific Forum. In May 2000, George Speight and armed supporters took the elected government of Fiji hostage because they were concerned about the power that Fijians of Indian descent had gained. It was a situation analogous to the one faced by the previous Labour government in New Zealand 13 years before, when Sitiveni Rabuka had mounted a military coup against the Fijian government for much the same reason. As the Lange government did in 1987, the Clark government at first voiced support for the reinstatement of the overthrown Fijian government, led by Mahendra Choudry. ${ }^{12}$ It criticized the decision of the Fijian Great Council of Chiefs to replace the Choudry government with an interim administration. However, like the Lange government, the Clark government quickly accepted that the status quo ante would not be restored. New Zealand's diplomatic response was to cut military ties with Fiji, and to ban people associated with Speight from entering New Zealand.

When, as in 1987, the Pacific Forum made no move to influence events in Fiji, the Clark government decided that this time it would not accept regional inaction. In conjunction with Samoa, Goff initiated a forum foreign ministers' meeting in Apia to draw up a blueprint for future forum action in similar circumstances. At the subsequent Pacific Forum meeting in October 2000, Helen Clark led the charge for the forum to commit itself to upholding democratic principles. Unlike her Labour predecessor, she was unwilling to defer to the preference of forum members to not interfere in the internal affairs of neighbouring states and to refrain from criticizing them publicly: the so-called "Pacific Way." Clark wanted the forum to adopt a new wayessentially, to defend Liberal Internationalist values. Assisted by Australia, Samoa and Kiribati, Clark was able to achieve this goal by getting the forum to agree to the Biketawa Declaration, which commits the forum to action to uphold democracy in the region. The Fijian interim prime minister attended the forum in a bid to head off the New Zealand and Australian initiative with the aid of Melanesian allies, but failed. Clark had made it clear that she would not attend any future forums if this one would not commit itself to the defence of democracy in the future. ${ }^{13}$

As soon as democracy returned to Fiji, in the shape of the August 2001 elections, New Zealand's relationship with Fiji improved. When the Commonwealth decided in December 2001 that Fiji should be readmitted to membership of the Commonwealth, New Zealand lifted its restrictions on contact with the Fijian government.

12 New Zealand Herald, 22 May 2000, p. A3.

13 New Zealand Herald, 31 October 2000, p. A1. 


\section{New Zealand Foreign Policy Under the Clark Govermment}

The Fiji crisis was the Clark government's first major test in the area of upholding democracy and human rights, and it performed well. Indeed, this government took a more robust stance on Fiji than the Lange Labour government had in 1987. Lange had been concerned about alienating Fiji and the rest of the Pacific Forum nations. The Lange government had also been less than robust on human rights issues in Iran and East Timor. ${ }^{14}$

The Clark government also proved to be a strong advocate of Commonwealth action against Zimbabwe for its abuse of democratic norms and human rights. After the Mugabe government passed laws to stifle dissent prior to the 2002 presidential election, Goff urged the forthcoming Commonwealth Heads of Government meeting to suspend Zimbabwe from the Commonwealth to demonstrate "the utter unacceptability of the increasingly dictatorial and abusive regime of Robert Mugabe."15 In this attitude, New Zealand was in line with Britain, Australia and Canada, but out of step with most of the African Commonwealth nations.

When the Commonwealth Ministerial Action Group (comprising Australia, Nigeria and South Africa) decided against suspension prior to the Zimbabwe election, the New Zealand government expressed disappointment and called for smart sanctions to be imposed on Zimbabwe's elite. Helen Clark said that if Mugabe were returned to power in the election, New Zealand would act alone if need be to impose measures against Zimbabwe. ${ }^{16}$ She considered it unfortunate that African leaders were unwilling to take action against Zimbabwe, and said that the Commonwealth looked silly in failing to act against abuses of human rights.

After the election, which Mugabe won, Zimbabwe was suspended from Commonwealth meetings, although not from the Commonwealth itself. The New Zealand government then moved to put in place targeted sanctions against members of the Mugabe government.

When Zimbabwe's one-year suspension from Commonwealth meetings expired in March 2003, the Labour government in New Zealand spoke out for the suspension to be continued, in the face of Nigeria's and South Africa's desire to see the suspension lifted. The suspension of Zimbabwe was extended until the Commonwealth Heads of Government meeting in December 2003, when it was decided that Zimbabwe should remain suspended indefinitely. Mugabe then announced that his country would leave the Commonwealth. Helen Clark said that Zimbabwe's leaving was not a disaster: the disaster would have been if the suspension had been lifted. ${ }^{17}$

\footnotetext{
14 David J. McCraw, "Idealism and Realism in the Foreign Policy of the Fourth Labour Government," Political Science, vol. 53, no. 2 (December 2001), pp. 27-28.

15 New Zealand Herald, 12 January 2002, p. A7.

16 New Zealand Herald, 5 March 2002, p. A1.

17 New Zealand Herald, 9 December 2003, p. A1.
} 
During the Labour government's first term, it also tried to advance the cause of human rights in Tibet. This was a delicate task for the government because New Zealand had an important trade relationship with China, the country denying the Tibetans their rights. In Parliament in June 2000, Phil Goff said that the government had consistently urged China to enter into dialogue with the Dalai Lama, the exiled Tibetan religious leader, and to consider ways in which the Tibetan people could be allowed to better express their identity. ${ }^{18}$ When Goff broached the issue of China's negotiating with the Dalai Lama with the Chinese foreign minister in late 2000, he was invited to visit Tibet, which he did in June 2001. The Labour government said that it did not challenge China's territorial integrity or its right to keep governing Tibet. Goff said that it would be pointless to challenge China's sovereignty in current circumstances. Instead, New Zealand should concentrate on encouraging China to give the Tibetan people more freedom to run their own affairs while protecting their language, culture and religion: "About all we can do is ask China to make that word autonomous in its Tibetan Autonomous Region have greater meaning in the practical sense."19

Goff spent four days in Tibet and at the end of it said he had raised concerns with Tibetan officials over restrictions on freedom of speech, harsh treatment of dissidents, restrictions on religion, and the need for greater autonomy to protect Tibetan culture and language: "In our view, long prison sentences for peaceful expression of a political view is contrary to international human rights standards." ${ }^{0}$

In May 2002, the Dalai Lama visited both Australia and New Zealand. The Chinese government, through its foreign minister, told the New Zealand government that it was undesirable that cabinet ministers meet the Dalai Lama. Nevertheless, the New Zealand prime minister and foreign affairs minister welcomed the Dalai Lama. This was in contrast to the Australian government, which refused to meet the Tibetan leader. Goff said that the New Zealand ministers met the Dalai Lama in his capacity as a spiritual leader. He acknowledged that the Chinese government preferred him not to meet the Dalai Lama, but said that this was a decision for New Zealanders to take. ${ }^{21}$

Even in the foreign policy of a Liberal Internationalist government, human rights cannot take priority over other considerations all the time. New Zealand's most important national interest is the expansion of its export markets, yet many of its trading partners are not democracies. Inevitably, some of their internal practices will not accord with Liberal values. The government's efforts to secure free-trade agreements with various Asian countries have sparked criticism that New Zealand is forming relationships

18 New Zealand Parliamentary Debates, vol. 585 (29 June 2000), pp. 3307-3308.

19 New Zealand Herald, 1 June 2001, p. A9.

20 New Zealand Herald, 5 June 2001, p. A7.

21 New Zealand Herald, 28 May 2002, p. A2. 
with countries whose human rights records are poor. The prospect of the Labour government's negotiating a free-trade agreement with China, for instance, was criticized in April 2004 by the Green Party's co-leader, Rod Donald, who said that unless New Zealand could force China to improve its record, especially concerning its use of child labour, the government should negotiate no further: "No country should put the economy ahead of human rights and environmental standards." 22 Trade Minister Jim Sutton said that the government would raise the issue of China's labour and environmental standards during negotiations, but that human rights issues were not a condition of the talks, and "I don't think we could expect single-handed to change China's policy in those regards." ${ }^{3}$

Shortly after the government began negotiations with China in December 2004, Rod Donald asked the minister of foreign affairs in Parliament why New Zealand was in talks with China when the latter's human rights record was poor. Phil Goff replied that if New Zealand stopped trading with countries it did not entirely agree with, New Zealand's living standards would suffer. ${ }^{24}$

The prime minister had earlier suggested that a free-trade agreement with the ASEAN countries would actually have a positive effect on human rights in the region. Forging closer ties, she said, would promote human rights. ${ }^{25}$

\section{International institutions}

Small states are alleged to give greater importance to international institutions in their foreign policies than larger powers, ${ }^{26}$ and it is true that all New Zealand governments have been conscientious supporters of the United Nations. This bipartisanship, however, conceals a difference in the parties' enthusiasm for the organization. For Labour, support for the United Nations is at the very centre of its foreign policy, as Liberal Internationalists believe that peace can be promoted by strengthening the authority of international institutions. The first Labour government was a fervent supporter of the League of Nations and played a role in the foundation of the United Nations. ${ }^{27}$ All subsequent Labour governments have been enthusiastic supporters of the institution. For the National Party, however, support is tempered by a Realist scepticism about the efficacy of the United Nations, and a preference to rely more on allies and friends. National Party

22 Bob Edlin, "Trade, not tirades, is path to modernising China," Independent, 21 April 2004, p. 8.

23 Edlin, "Trade, not tirades."

24 New Zealand Herald, 10 December 2004, p. A4.

25 Radio New Zealand Newswire, 30 November 2004, 05:30.

26 East, "Size and Foreign Policy Behavior," p. 557, p. 560.

27 David McCraw, "The Advent of Liberal Internationalism in New Zealand's Foreign Policy," Political Science, vol. 55, no. 2 (December 2003), pp. 47-50 and 57-58. 
leader Bill English would say in 2002, concerning the Iraq crisis: "As important as the United Nations is as an international force, there are other international relationships that for us are more strategic." ${ }^{28}$

The Clark government has been a strong promoter of the role of the United Nations, and it has been quite willing to criticize New Zealand's friends and allies when they have failed to give the United Nations the support that the government believed they should. In February 2000, for instance, Phil Goff criticized the United States for failing to pay its outstanding UN bill of $\$ 1.6$ billion: "New Zealand, a country which has always paid its fees on time and without conditions, questions the equity of larger countries with substantial financial resources not pulling their weight." ${ }^{29}$ The United States, he said, was the key defaulter.

The following September, the minister of foreign affairs and trade criticized the Australian government for threatening noncooperation in the future with United Nations human rights investigators. The Australian move had come after a United Nations Committee on Economic, Social and Cultural Rights had issued a report indicating deep concern over Aboriginal disadvantages in employment, health, housing and education. Goff urged the Australians to "stay engaged" with the United Nations rather than downgrading cooperation. He said that since New Zealand and Australia were signatories to United Nations treaties and the standards they established, they had to be open to listening to criticism. ${ }^{30}$

Even when the Labour Coalition government disagreed with United Nations policy, it indicated a willingness to comply with the relevant rulings. In April 2000, the government announced that it was no longer in favour of United Nations trade sanctions against Iraq. These, Goff said, were hurting ordinary Iraqis and not the ruling elite. Goff wanted better targeted "smarter sanctions" that would include the freezing of assets and bank accounts overseas, and a ban on foreign travel. The minister of foreign affairs and trade indicated, however, that New Zealand would remain bound by trade sanctions as long as they were United Nations policy. ${ }^{31}$

New Zealand's most tangible means of supporting the role of the United Nations has been its participation in United Nations peacekeeping forces. The Labour-led government responded positively to several United Nations requests to extend the commitment of New Zealand troops to the peacekeeping force in East Timor, despite the strain on the army of keeping a full battalion there. The government also contributed soldiers to a British-

28 Bill English, "Doing the Right Things for the Right Reasons," New Zealand International Review, vol. 27, no. 5 (September-October 2002), p. 6.

29 New Zealand Herald, 24 February 2002, p. A5.

30 Sunday Star-Times, 3 September 2000, p. A2.

31 Audrey Young, "Time to End Misery of Iraq blockade says NZ," New Zealand Herald, 19 April 2000 , p. A5. 
led peacekeeping force in Afghanistan. This force, consisting of units from 15 nations, was authorized by the Security Council. In 2003, after a United Nations resolution urged members to help with the reconstruction of Iraq, New Zealand sent some 60 army engineers to that country, as well as mine clearance experts.

The Labour coalition government's commitment to the United Nations was probably most clearly demonstrated during the 2003 crisis over Iraq, when New Zealand refused to support the United States, Britain and Australia in their military intervention in Iraq, because such action had not been authorized by the United Nations.

Before the American and British intervention, the Clark government's position had been that the United Nations weapons inspectors, who were trying to determine whether Iraq had disposed of its weapons of mass destruction, should be given time to finish their work. If, after that, the United Nations authorized military action against Iraq, New Zealand would contribute medical or logistical support. ${ }^{32}$ The Green Party attacked this stance, saying that even if the United Nations Security Council authorized force, this would not make it right. Clark retorted that "you can't flick multilateralism on and off when it suits you and say you don't want it when you don't get the result you want." ${ }^{33}$ She said that New Zealand had always fulfilled its obligations as a "conscientious" member of the United Nations. Later, she would say: "If we are going to pick and choose Security Council resolutions we uphold, then we contribute to undermining the organisation." ${ }^{34}$

For Helen Clark, support for the premier international institution was more important than anti-militarism when these two elements of Liberal Internationalism clashed. It was also more important than advancing the cause of human rights by deposing Saddam Hussein. When the United States and Britain attacked Iraq in late March 2003, without specific United Nations authorization, Prime Minister Clark said, on 17 March, that she did not accept the argument that an invasion of Iraq could be justified by its liberation from Saddam Hussein: "A regime change is not something that the UN is mandated to do." She also said that it was a very serious thing to thumb one's nose at the Security Council. ${ }^{35}$

In Parliament, Clark expressed "profound regret" that "close friends" had chosen to act outside the Security Council and thus set a dangerous precedent. ${ }^{36}$ After the leader of the National Party suggested that New

32 New Zealand Herald, 22 January 2003, p. A7.

33 New Zealand Herald, 29 January 2003, p. A1.

34 Gordon Campbell, "A Rock and a Hard Place," New Zealand Listener, vol. 187, no. 3277 (1-7 March 2003), p. 20.

35 Waikato Times, 17 March 2003, p. 2.

36 New Zealand Parliamentary Debates, vol. 608 (18 March 2003), p. 4111. 
Zealand should at least contribute some medical assistance, Clark declared that the government would not be assisting a war for which there was no case at this time: "Without the United Nations, multilateralism and respect for the international rule of law, the world's prospects would be bleak indeed." A return to an earlier era, where might was right, was not in New Zealand's interests, nor in the interests of the international community at large. If all nations of goodwill did not move rapidly to support a reassertion of the authority of the United Nations, then others might well feel able to use that precedent. ${ }^{37}$ Clark said that after the war, New Zealand would contribute to any United Nations peacekeeping force in Iraq, but not one organized by the United States only. ${ }^{38}$

\section{Anti-militarism and disarmament}

A small state has been defined as one that cannot "obtain security primarily by use of its own capabilities," ${ }^{39}$ and certainly New Zealand governments have always considered New Zealand to be in that category. Historically, governments of all stripes have seen New Zealand's isolated geographic position as a vulnerability, and sought to counter it by alliances with friendly "great powers," first Britain and then the United States. The first, second and third Labour governments all adopted this strategy, even though their Liberal Internationalist ideology opposed security alliances and favoured disarmament. This came about because of the inability of the United Nations to provide the system of universal collective security that Labour preferred. National Party governments, on the other hand, have been enthusiastic supporters of New Zealand's alliances and have given them high priority in their foreign policies.

It is true, nevertheless, that in the postwar era, defence has never had the same importance as it has had in neighbouring Australia; this has been attributed to New Zealand's greater remoteness from the presumed source of threats, Asia, and the fact that it is shielded by a well-armed ally, Australia. ${ }^{40}$ As the last perceived threat in the region, from a militant China, faded away in the 1970s, the underlying ideological differences of the major parties on defence began to assert themselves. The fourth Labour government of 19841990 sacrificed New Zealand's security alliance with the United States, ANZUS, in order to retain a disarmament policy that its ally opposed. This disarmament policy was a ban on the entry into New Zealand ports of nucleararmed and nuclear-powered ships. Labour's reasoning was that the greatest

37 Sunday Star-Times, 23 March 2003, p. C3.

38 New Zealand Herald, 25 March 2003, p. A5.

39 R. I. Rothstein, Alliances and Small Powers (New York: Columbia University, 1968), p. 29.

40 Hugh White, "Refocusing the dialogue on strategic co-operation," New Zealand International Review, vol. 28, no. 1 (January-February 2003), p. 3. 


\section{New Zealand Foreign Policy Under the Clark Government}

threat New Zealand now faced was the nuclear-arms race. ${ }^{41}$ This government, however, still wished to retain New Zealand's security link with Australia.

The current Labour-dominated government has demonstrated a Liberal Internationalist anti-militarism by radically restructuring New Zealand's defence force, and in the process it has further loosened the security ties between New Zealand and its friends and allies.

The Labour-led government moved early to restructure the defence force to prioritize peacekeeping and civil defence tasks. This plan was based on a report by Parliament's foreign affairs and defence select committee, which recommended that since no political party was willing to spend more on defence, New Zealand should rationalize its capabilities along the lines of those that were currently most useful. ${ }^{42}$ Thus, instead of trying to fund inadequately a broad-based range of air, sea and land capabilities, New Zealand should have a more focussed and viable force for the same money. Since peacekeeping and civil defence tasks were what the military had been doing most of in recent years, and since those tasks were also the most congenial to Labour's anti-militarist outlook, the Labour government decided to prioritize the capacities that best supported those roles. Thus the Army was to be better funded at the expense of the combat arms of the Air Force and Navy. Accordingly, the Labour government, while funding new equipment for the Army, cancelled the previous government's deal with the United States for new strike fighters and then, a year later, disbanded the existing air combat arm of the Air Force: two squadrons of Skyhawks. The government also cancelled the upgrade of the radar of the Orion maritime surveillance aircraft, which meant an end to their anti-submarine capability. Finally, the government announced that it would buy no more frigates. When the most elderly frigate was retired in 2005 , the government would look to replace it with a multi-role patrol vessel, rather than a combat frigate.

These moves, all of which downgraded the fighting capacity of the Air Force and the Navy, concerned both the United States and Australia, which hoped that New Zealand would maintain forces capable of augmenting their own in coalition operations in the region or further afield. The Australian Defence White Paper of 2000 noted: "We would regret any decision by New Zealand not to maintain at least some capable air and naval combat capabilities. Such forces would allow a more significant contribution to be made to protecting our shared strategic interests, especially in view of the essentially maritime nature of our strategic environment." 33

41 David Lange, "Facing Critical Choices," New Zealand International Review, vol. 12, no. 4 (JulyAugust 1987), p. 2.

42 Inquiry into Defence Beyond 2000, Report of the Foreign Affairs, Defence and Trade Select Committee, Appendix to the Journals of the House of Representatives 1999, I. 4D., p. 59.

43 Defence 2000: Our Future Defence Force (Canberra: Commonwealth of Australia, 2000), p. 42. 
The Clark government was apparently not influenced by the views of its allies. After the decision to cancel the upgrade of the Orions in August 2000, the prime minister admitted that the Cabinet had ignored warnings from foreign affairs and defence officials that such an action would upset New Zealand's defence partners. ${ }^{44}$ Defence minister Burton conceded that Australia had wanted the refit of the aircraft with sophisticated submarine detection electronics to proceed. The Australian defence minister publicly expressed "disappointment" at the decision. These actions contradicted the government's publicly expressed defence policy objective of maintaining a close defence partnership with Australia in pursuit of common security interests. ${ }^{45}$

The Labour government believed that not only could New Zealand not afford the equipment necessary to support the strategies of its allies, but there was no need to do so because those strategies were wrongly conceived. For Clark, regional security was best achieved by non-military means. In 1994, she had said that New Zealand's security would rest on relationships built with Asia-Pacific nations. ${ }^{46}$ The Government's Defence Framework paper elaborated on this by saying that New Zealand could best contribute to regional stability by promoting comprehensive security through a range of initiatives, including diplomacy, trade links, development assistance and the pursuit of arms control and disarmament. ${ }^{47}$

Clark and the Labour Party are also declared supporters of the Liberal Internationalist concept of common security, which is based on the premise that no country can make itself militarily secure without creating insecurity in others, so that building up armed forces is counterproductive and wasteful. True security can only be found in co-operation with other countries, rather than in competition with them. Whereas collective security (previously favoured by Labour) aims at deterring others through the threat of combined force, common security tries to move away from the use of force altogether. ${ }^{48}$ The 1993 election manifesto of the Labour Party pledged Labour to work to promote common security in the Pacific region, realizing that past military alliances were no longer an adequate basis for meeting the region's postCold War needs. ${ }^{49}$

The Labour government was initially very wary of joining Australia in sending troops to the Solomon Islands in 2003 after law and order broke

44 John Armstrong and Greg Ansley, “Overseas Backlash as Orions sidelined,” New Zealand Herald, 24 August 2000, p. A1.

45 Armstrong and Ansley, p. A1.

46 Waikato Times, 23 March 1994, p. 7

47 The New Zealand Ministry of Defence, The Government's Defence Policy Framework, New Zealand government, June 2000, p. 2.

48 Independent Commission on Disarmament and Security Issues, Common Security: A Blueprint for Survival (New York: Simon and Schuster, 1982), particularly pp. 8-10.

49 New Zealand Labour Party, Jobs. Growth. Health: Labour's Manifesto for New Zealand (Wellington: MMSC Ltd, 1993), p. 128. 
down there. After the Solomons government asked for help, Australia was ready to lead a rescue mission and asked New Zealand to participate. The New Zealand government was uneasy about being seen to intervene like "big brother" in the affairs of a small Pacific neighbour: the parallels with Iraq were too close for comfort. Cabinet eventually agreed to send police and logistics personnel from the military, but initially declined to send infantry like the Australians. New Zealand told Australia that it would keep an infantry company on standby to send if the need arose..$^{50} \mathrm{~A}$ month later, when Australia requested the troops, they were sent. The Australian minister of foreign affairs later publicly mentioned New Zealand's hesitation, and its concern that Australia was throwing its weight around in the Pacific. He said that New Zealand and other Pacific nations were now comfortable with Australia's role. ${ }^{51}$

Liberal Internationalism, however, has not always dictated Labour's policy. After the terrorist attacks on New York in September 2001, Clark offered the United States a New Zealand special forces unit for any military intervention in Afghanistan, an offer that was accepted. New Zealand SAS troops joined the forces of several other nations for a tour of duty in Afghanistan in late 2001. In 2004, it was announced that the unit would return to Afghanistan for another tour. At the Americans' request, the Labour government also dispatched a frigate to the Persian Gulf to join a multinational naval task force trying to interdict the movements of terrorists.

These two policies reflect Realist decisions to further the national interest. American officials had warned the government privately that its response to the September 11 attacks would be treated as a touchstone for future relations between the countries. There was also the fact that the government was hoping to negotiate a free-trade agreement with the United States. ${ }^{52}$

The Labour government, however, has made it plain that it has no interest in resuming a formal military relationship with the United States. Shortly after becoming the Labour Party's leader in late 1993, Clark said that the ANZUS alliance was "out of time" and had "no relevance to New Zealand's security needs today." ${ }^{53}$ Even if the obstacles to better defence relations with the United States were removed by a resolution of the ship ban dispute, she said, Labour would not be interested in resuming a defence relationship. ${ }^{54}$

50 Tracy Watkins, “Anzac tension over Solomons," Stuff-Dominion Post-Local News 10 November 2003, p.1, www.stuff.co.nz, retrieved (31 March 2005) from a library newspaper database run by Independent Newspapers Ltd called Newztext Plus, which is accessible at http://io.knowledgebasket.co.nz/magz/007-01.html.

51 Tracy Watkins, "Downer digs at NZ Solomons hesitancy," Dominion Post, 22 December 2003 (second edition), p. 2 p. 1.

52 John Armstrong, "Blunt U.S. hint led to offer of troops," New Zealand Herald, 8 January 2002,

53 Waikato Times, 23 March 1994, p. 7

54 New Zealand Herald, 18 April 1994, p. 1. 
Clark has indicated that her government has no intention of modifying, let alone repealing, the law prohibiting port visits by nuclear-armed and nuclear-propelled ships, which sparked the rift with the United States. Even though the United States has removed all tactical nuclear weapons from its surface ships, the policy is too symbolic of Labour's commitment to nuclear disarmament to be modified. Clark believes that being nuclear-free has been a great asset to many new relationships that New Zealand has built, and has enabled New Zealand to take a leadership role on nuclear disarmament. ${ }^{55}$ During 2002, the deputy prime minister admitted that the ships ban was an obstacle to the conclusion of a free-trade agreement with the United States, but there would nevertheless be no change in the policy. ${ }^{56}$

The Clark government's emphasis on nuclear disarmament reflects a major element of Liberal Internationalism. Addressing the United Nations in her first year, the prime minister said that New Zealand's "key preoccupations" in the United Nations in coming years would be on issues of disarmament and security, human rights, the environment and development: "Our passion for nuclear disarmament is well-known." Clark said that years of working with others for a Comprehensive Test Ban Treaty had paid off, and now the goal was nothing less than the total elimination of nuclear weapons. ${ }^{57} \mathrm{~A}$ start had been made at the Non-proliferation Treaty Renewal Conference in May 2000, when New Zealand and its six allies in the New Agenda Coalition, which had been formed in 1998 to press for total nuclear disarmament, had presented the nuclear powers with an agenda of desirable actions to be taken. These included a no-first-use of nuclear weapons declaration, and a de-activation of nuclear weapons. A small success was gained when the five nuclear powers on the Security Council committed themselves to the goal of complete elimination of their armaments, although without any hint of a timetable. ${ }^{58}$ The same year Brazil and New Zealand presented the United Nations with a resolution calling for the establishment of a Southern Hemisphere Nuclear Weapons Free zone. It won overwhelming support.

\section{Free Trade}

Small nations are thought by scholars to give economic matters greater priority in their foreign policies than larger nations do.$^{59}$ In New Zealand's case, it is true that the most important national interest is the protection

55 Tracy Watkins, "Nuclear fallout," Dominion Post, 6 April 2002, p. 13.

56 New Zealand Herald, 7 October 2002, p. A6.

57 Record: New Zealand Foreign Affairs and Trade, vol. 9, no. 3 (September-October 2000), p. 11.

58 Record: New Zealand Foreign Affairs and Trade, vol. 9, no. 3 (September-October 2000), p. 85.

59 East, "Size and Foreign Policy Behavior," p. 560. 
and expansion of the country's export trade, and that all governments are subject to this imperative. Not only do exports account for about a quarter of the country's gross national product, but these exports consist largely of agricultural products which face formidable protective barriers in many countries of the world. Both of New Zealand's major political parties are committed to seeking the lowering of trade barriers in other countries, and since New Zealand's own tariffs were drastically reduced after 1984, both parties now support free trade.

It was a National Party government that pioneered New Zealand's conversion to freé trade by concluding a free-trade agreement with Australia in 1983. National, like Labour, had previously protected New Zealand's manufacturers. The Realist outlook supports any trade strategy that is in the national interest, although its emphasis on self-reliance would seem to favour protectionism. However, if free trade is judged the best vehicle for enhancing the nation's economic well being, then Realists would support that. National now sees free trade as being in New Zealand's national interest.

Liberal Internationalism believes that free trade between countries contributes to peace as well as increases wealth. Although historically the New Zealand Labour Party has not favoured this element of Liberal Internationalism because of the threat it posed to employment in protected industries, the fourth Labour government in 1984 became a convert to free trade as a way of making New Zealand's economy more efficient.

The Clark government, which is New Zealand's fifth Labour-dominated government, has been notable for its efforts to secure bilateral free trade deals with a number of countries around the Pacific. This strategy appears to be a contradiction for a Liberal Internationalist government that is committed to multilateralism in trade as in other things, but the government does not see it as such. In the Clark government's eyes, these bilateral deals are both a "hurry up" to multilateral negotiations and a fallback in case those negotiations fail. Trade minister Jim Sutton indicated in 2003 that New Zealand's focus remained firmly on the Doha round of the World Trade Organization negotiations. The main reason that the government had been pushing bilateral deals along was "because it adds momentum to the multilateral negotiations." People would worry about being left out "and that concentrates their minds." ${ }^{60}$ The Doha round, however, broke down in September of that year, adding impetus to fallback arrangements. Another driver of bilateralism has been the relative failure of the regional economic organization, APEC, to live up to its promise of freeing up trade. Helen Clark came to power believing that APEC had run out of steam as an instrument to hasten trade liberalization and that agreements between

60 Bob Edlin, "Pragmatic government elevates China in trading priorities," Independent, 21 January 2004 , p. 8. 
smaller groups of countries that wanted to move faster towards the goal were the way to go. ${ }^{61}$

The pursuit of bilateral trade agreements is a Realist policy, because securing preferential access is in New Zealand's national interest if multilateral negotiations fail. Despite Clark's belief that free trade will advance the cause of human rights, the prime motivation for the policy is not the Liberal Internationalist one of advancing peace, but the Realist one of increasing New Zealand's economic security.

The government's principal targets for bilateral agreements were Singapore and Chile, both of which had open economies like New Zealand's and were also disappointed with the progress made on trade liberalization by multinational and regional organizations. In 1999, New Zealand, under a National Party government, had suggested such an agreement to Singapore. Although both governments were doubtful that there would be much direct economic benefit to either from an agreement, it was thought that it might have political benefits in stirring interest among other potential partners. ${ }^{62}$ If enough APEC economies joined in, it might force the others to come along for fear of being disadvantaged.

An agreement with Singapore on a Closer Economic Partnership took only a year to negotiate and was signed in November 2000. Although New Zealand had hoped that Chile would be a third partner in the agreement, such a deal has proved more problematic than the one with Singapore. The main sticking point has been Chile's reluctance to expose its dairy farmers to competition from more efficient New Zealand producers. Nevertheless, negotiations have continued, and at the APEC summit in 2002, New Zealand, Singapore and Chile announced their intention of having a comprehensive three-nation free-trade deal signed by October 2004.

The 2002 APEC summit also saw the initiation of talks about a New Zealand economic partnership with Mexico. The two governments agreed to study the benefits of a free-trade agreement. Mexico is New Zealand's biggest trading partner in Latin America and is already in a free-trade association with the United States and Canada.

The biggest prize in the Labour government's bilateral strategy is a freetrade deal with the United States, which is estimated to be worth NZ $\$ 1$ billion a year to New Zealand. ${ }^{63}$ Clark broached the subject with President Bush at the 2001 APEC summit and received encouragement that such an agreement

61 John Armstrong, "Clark questions Apec's Asia-Pacific relevance," New Zealand Herald, 11 November 2000 , p. A4.

62 Stephen Hoadley, Negotiating Free Trade: the New Zealand-Singapore CEP Agreement (Wellington: New Zealand Institute of International Affairs, 2002), pp. 21-22.

63 John Armstrong, "Anzac spirit evaporates on US trade," New Zealand Herald, 17 December 2001, p. A6. 


\section{New Zealand Foreign Policy Under the Clark Government}

might be possible once the president had received the pending congressional authority to conclude such deals. New Zealand knew that both Chile and Singapore were already negotiating for a deal and that Australia was intent on opening negotiations. The Labour government believed that New Zealand's competitive position in the American market could be undermined if Australia got superior access to that market. It hoped that New Zealand could make a joint approach with Australia, but found the Australians reluctant to involve New Zealand in their negotiations. ${ }^{64}$ The Australians thought New Zealand would bring a fresh set of difficulties to the table which would only complicate Australian efforts.

In October 2002, however, there appeared to be a breakthrough when the Bush Administration's trade representative announced his backing for an agreement with New Zealand to complement the one being negotiated with Australia. The announcement came after an intensive eight-week lobbying campaign in Washington, headed by New Zealand's ambassador to the United States. It also followed a few days after Prime Minister Clark had announced the commitment of a New Zealand frigate to the Persian Gulf to help in the interdiction of $\mathrm{Al}$ Qaeda members.

Helen Clark herself flew to the United States in December 2002 to help the process along. It was critical, she said, that New Zealand took every opportunity to push its case in the United States: the prize was no less than a special working partnership with the world's largest economy ${ }^{65}$ The prospects of an agreement chilled again, however, early in 2003, after differences between the two countries over Iraq. Not only did the Labour government not support the American intervention in Iraq, but Clark annoyed the American government by saying publicly that the war would not have occurred if Bush's Democratic opponent at the 2000 presidential election, Al Gore, had been president. The American embassy in New Zealand described the comment as "regrettable." ${ }^{66}$ Clark was forced to offer apologies after being told that her comments might damage the New Zealand lobbying effort in Washington. In May 2003, the American embassy stated that the United States was not prepared to enter into negotiations with New Zealand "at this time," though it did not rule out the possibility of such talks in the future. ${ }^{67}$

Early in 2004, the United States concluded a trade deal with Australia. The concessions Australia obtained for agricultural products, however, were very limited, and finance minister Cullen said: "This is not the big bang FTA that everybody feared." His analysis was that it offered some gains for some parts of the Australian economy, but not huge gains overall and "certainly

64 Armstrong, "Anzac spirit."

65 New Zealand Herald, 10 December 2002, p. A3.

66 New Zealand Herald, 5-6 April 2003, p. A1.

67 Audrey Young, "US toughens trade stance," New Zealand Herald, 24-25 May 2003, p A1. 
not huge damage to us as a result." ${ }^{" 68}$ The government vowed to continue its own efforts to negotiate an agreement, but did not expect any progress until after the 2004 presidential elections.

The New Zealand government sought a free-trade agreement with two other countries-Thailand and China. Just before the 2003 APEC summit in Bangkok, Helen Clark announced that New Zealand would negotiate a deal with Thailand. In October 2003, when Chinese President Hu Jin-tao visited New Zealand, the government announced that the two governments would begin talks on a framework for trade and economic co-operation. This might lead on to a full free-trade agreement. Indeed, Helen Clark reportedly told a visiting Chinese official in early 2004 that she wanted New Zealand to be the first Western nation to achieve a free trade deal with China. ${ }^{69}$ Negotiations opened between China and New Zealand in December 2004.

\section{Conclusion}

The Clark government's foreign policy has shown a strong Liberal Internationalist emphasis, as is traditional with Labour Party governments. The government was strong in its defence of both democracy in Fiji and human rights in Zimbabwe, and it spoke out firmly for Tibetan rights, although New Zealand has an important relationship with China. The Clark government has also consistently upheld the role of the United Nations, most notably with regard to Iraq, when New Zealand's friends and allies were taking a different line. The Labour government demonstrated its antimilitarism by radically restructuring the New Zealand defence force to focus on peacekeeping and disaster relief, and its commitment to free trade has been shown in its negotiation of free trade agreements with some fellow APEC members. The government has thus far performed well in all the areas that Liberal Internationalism emphasizes, and might well be seen as the most Liberal Internationalist government New Zealand has had so far. Three of the four previous Labour governments did not support free trade, and the one that did had a less robust record on human rights than Clark's. National governments have not been Liberal Internationalist governments.

Like all governments, however, the Clark government has not been able to conduct a foreign policy completely consistent with its ideological outlook. Despite its anti-militarism, the Labour government offered military forces to the United States for its campaign against the Taliban in Afghanistan, and later contributed a frigate to the multinational naval force interdicting terrorist movements in the Persian Gulf. The desirability of closer economic

68 New Zealand Herald, 11 February 2004, p. A6.

69 Fran O'Sullivan, "World first for NZ in China trade pledge," New Zealand Herald, 3 April 2004, p. A1. 
partnerships with certain Asian countries has outweighed any qualms about their human rights records, and the lack of progress at the multilateral negotiations of the Doha round has led to a number of bilateral deals as a second-best option. The deviations from a Liberal Internationalist foreign policy have, nevertheless, been relatively few.

Of the various elements of Liberal Internationalism in the Clark government's foreign policy, it would seem that support for the United Nations and the promotion of free trade are particularly strong, with antimilitarism and promotion of human rights being of slightly lesser importance. It is notable that these stronger elements are the ones that are also supported by the National Party, if perhaps not always to the same degree, and thus may be seen as national interests as well as ideological preferences. An emphasis on economic matters in foreign policy and support for international institutions are alleged characteristics of a small state's foreign policy, but the Labour government's anti-militarism and its promotion of human rights owe more to its Liberal Internationalist outlook than to New Zealand's size.

The University of Waikato, Hamilton, New Zealand, January 2005 